\title{
MANAGEMENT DECISION SUPPORT SYSTEM IN PROCUREMENT OF AGROINDUSTRY COMPLEX
}

\author{
Drago Cvijanović1 ${ }^{1}$ Ivan Milojević ${ }^{2}$ Milan Mihajlović ${ }^{2}$
}

date of paper receipt:

05.04.2019.

Review Article date of sending to review:

08.04.2019.

doi:10.2478/eoik-2019-0008 date of review receipt:

16.04.2019.

UDK: 338.43:658.71

${ }^{1}$ University in Kragujevac, Faculty of Hotel Management and Tourism, Vrnjačka Banja, Serbia

${ }^{2}$ Military academy, Belgrade, Serbia

\begin{abstract}
The optimal procurement is achieved by monitoring them from the very beginning of the planning process. Procurement planning, as one of the basic functions of procurement management, determines the goals, tasks and the way of their realization. The realization of procurement plans is realized through the purchase function of business entities, both from the domestic and foreign markets.

The specifics of procurement of agro-industrial complex require continuity as a basic requirement. The importance of procurement consists in the fact that the level of reproductive capacity of the agro-industrial complex depends significantly on the normative organization, organization and quality of procurement. The goal of procurement is precisely, timely, quality and under the most favorable conditions, the acquisition of funds on the market, in order to meet the needs for the continuous operation of the companies from the agro-industrial complex.
\end{abstract}

\section{Keywords:}

procurement, management, agroindustrial complex 


\section{INTRODUCTION}

The agro-industrial complex significantly reflects the continuous provision of funds. With such means, the choice of the structure of resources is dominant as a fact that defines a potential agroproducer, which is also the subject of research in this paper.

The procurement function is realized through several subprocesses: planning; market research and price monitoring; contracting; tracking billing maturity. To this end, the application of scientific methods in the study and market research, the formation and engagement of expert teams for the execution of individual arrangements, the implementation of complex economic analyzes, are essentially a consideration of all relevant factors that would ensure the execution of the procurement of funds under the most favorable conditions.

In addition to the elements of economy, for each procurement of resources, justification from the point of view of real needs is important. Well-designed pledge plans represent a decision on what, how much and at what affordable price they are to procure.

Economic analysis in the decision-making of resources is an analysis of the future of events and phenomena aimed at finding the most rational solutions based on the collected data in order to make an optimal decision.

The cost of funds is one of the most important elements in the process of obtaining funds. If the framework for the freedom to form a bidder's price is higher, that is, if the market of imperfect competition is in the more complicated, the process of securing the funds being implemented. When forming prices on the market, it should be taken into account that the most common selling is done directly, which differentiates it from controlled market goods. Since for the needs of the agro-industrial complex products are sold directly to buyers, the degree of control over the price is higher than the sale of controlled goods.

Based on the subject of the research, the aim of the research is to show which procurement procedure has the greatest value in terms of the speed of implementation, which affects the adequate provision of funds from the producers of the agro-industrial complex. For the purposes of this paper, quantitative decision-making methods will be used as a means of selecting an optimal procurement procedure, based on the criteria for selecting the most favorable supplier. For this purpose, the method of analytical-hierarchical processes will be used taking into account simplicity and wide application in various research.

\section{QUANTITATIVE MODEL FOR HELP IN MANAGEMENT DECISION}

There are a number of methods and techniques that have been developed over time and used to solve decision-making problems in real-life situations, and can all be divided into two large groups: methods of single-criterion decision making and multi-criteria decision making. Each decision support system consists of at least three subsystems: 1 a database that forms part of the decision support system in which the organization's input and output data is stored2; model databases 3 that represent a decision support system component that consists of business decision models. Each model solves a particular problem in a particular business process. Their task is to generate output based on input data and decision models, on the basis of which the decision-maker can make decisions; the user interface that should enable, as easy as possible, the communication between the decision support system and the user.

\footnotetext{
${ }^{1}$ Sprague, R.H, Carlson, E. D.: Building Effective Decision Support System, Prentice Hall, Englewood Cliffs, 1982, navedeno u Suknović M., Delibašić B., Poslovna inteligencija i sistemi za podršku odlučivanju, Fakultet organizacionih nauka u Beogradu, Beograd, 2010, str. 8-9.

${ }^{2}$ Mihajlović. M., Dašić, M., Pamučar, D.: Primena AHP metode prilikom nabavke opreme za objekte ishrane u sistemu odbrane, 34. Simpozijum o operacionim istraživanjima, SYM-OP-IS 2012, str. 409-412

${ }^{3}$ Rađenović, Ž.: Uticaj politike konkurencije na državnu pomoć i javni sektor u okviru jednstvenog tržišta Evropske unije, Facta universitatis - series: Economics and Organization, Vol. 12, br. 1, 2015, str. 83-95
} 
The problem 4 of determining the significance of the criteria in the realization of the provision of funds for the agro-industrial sector 5 includes several continents, starting from planning.6 The term criterion takes an important place in the decision-making process on the most favorable bid. According to the direction of agreement, the following are distinguished: 7 income criteria; expense criteria and non-monotonic criteria.

There are numerous methods for solving the multi-criteria decision-making model, which can be divided on the basis of several criteria, and as the best in today's time, they are distinguished: ELECTRE method; method PROMETHEE; AHP methods (analytical hierarchical processes); TOPSIS method; method SAW et al.

For research purposes, we will use the AHP method, which represents the method of multi-criteria decision making, designed to assist decision-makers in solving complex decision-making issues involving a larger number of decision-makers, a greater number of criteria in multiple periods. Methodologically, AHP is a multi-criteria technique that is based on explaining a complex problem in a hierarchy. The method of analytical-hierarchical processes holds all the parts of the hierarchy in connection, so it is easy to see how the change of one factor influences other factors.

The decision-making process is often very complex because of the presence of conflicting targets among the available criteria or alternatives. The problem is to choose an alternative that will best meet the set goals. The field of application of this method is multi-criteria decision-making where, based on a defined set of criteria and attribute values for each alternative, the choice is most acceptable.8 For easier application of this method, a software tool from the Expert Choice decision support system was developed.

The process of implementing the AHP method involves four basic phases:9 Structuring a problem that consists of decompressing any compile decision problem in a series of hierarchies, where each level represents a smaller number of manageable attributes. They then decompose into another set of elements corresponding to the next level. This hierarchical structuring of any decision problem in this way is an effective way of dealing with the complexity of real problems and identifying significant attributes in order to achieve the overall goal of the problem. Data collection is the beginning of the second phase of the method of analytical-hierarchical processes. The decision maker assigns relative estimates in attribute pairs, one hierarchical level, for all levels of the entire hierarchy. The most familiar scale used to assign weight is Saaty's nine-point scale.

Estimating relative weights implies that the matrix of comparison, by pairs, translates into problems of determining its own values, in order to obtain normalized and unique own vectors, with the weights for all attributes to each level of the hierarchy.

Determining the solution to the problem is the last phase which involves finding the so-called. composite normalized vector. After the vector of the order of the values of the criteria in the model is determined, in the next round it is necessary to determine within each observed criterion, the order of importance of the alternative in the model with respect to the same procedure. The mitigating circumstance when using any method of multi-criteria decision-making is the fact that all software is supported.10

\footnotetext{
${ }^{4}$ Petrović, D., i dr.: Menadžment i organizacija, Fakultet organizacionih nauka, Beograd, 2012, str. 40.

${ }^{5}$ Vilke, R., Gedminaite-Raudone, Z., \& Cvijanović, D. (2019). Future drivers of rural prosperity in knowledge age:

Lithuanian case. Ekonomika poljoprivrede, 66(1), 143-157.

${ }^{6}$ Čavlin, M., Žugić, R., \& Prebiračević, V. (2017). Karakter planiranja kao funkcije menadžmenta. Oditor - časopis za

Menadžment, finansije i pravo, 3(1), 102-113.

${ }^{7}$ Pavličić, D.: Teorija odlučivanja, Ekonomski fakultet Beograd, Beograd, 2010, str. 176.

${ }^{8}$ Jovović, D., \& Jovović, D. (2018). Konkurentnost prehrambene industrije Republike Srbije. Ekonomika poljoprivrede, 65(1), 49-64.

${ }^{9}$ Čupić, M., Suknović, M.: op. cit., str. 334-337.

${ }^{10}$ www.odlucivanje.fon.rs
} 


\section{APPLICATION OF ANALYSIS MODEL}

Using the method of the AHP method, we analyzed the data we came up with by researching 120 procurement of funds carried out in the entities of the agro-industrial complex in the Republic of Serbia. Procurement relates to funds, and for research purposes, they were grouped into three categories. The first category consisted of 60 procurements realized through open procedure where the lowest offered price was considered as a criterion. The second category consisted of 30 procurements realized through open procedure whereby the most economically advantageous offer was taken as the criterion, where $70 \%$ and $30 \%$ were used as elements of this criterion. In the third category, 30 procurements were carried out in the negotiation procedure with the announcement of a call for bids, in which the most economically advantageous tender with the elements of the deadline for delivery, obligations in terms of maintenance of the maintenance period and the capacity of the tenderer was taken as the criterion.

Bearing in mind that there are different elements of the criteria, the model takes the ones that are most important for providing continuous securing of the assets of the agro-industrial complex, starting from the conditions of performing this economic activity. Criteria on the basis of which the alternatives are evaluated in this case are:

Table 1. Criteria for the selection of an optimal bidder (calculation of the author)

\begin{tabular}{|c|c|c|}
\hline No & Tag criteria & Description criteria \\
\hline 1. & K1 & The speed of securing funds. \\
\hline 2. & K2 & Quality of assets. \\
\hline 3. & K3 & The degree of execution expressed as a percentage. \\
\hline 4. & K4 & Safety, which refers to the time of realization. \\
\hline
\end{tabular}

Using the Delphi method11 the values of the criteria and their relative weight are estimated:

K1 - The speed of securing funds $(0,30)$,

K2 - Quality of assets $(0,20)$,

К 3 - The degree of execution expressed as a percentage $(0,20)$ и

K4 - Safety, which refers to the time of realization $(0,30)$.

The decision matrix in this case is shown in the table 2 :

Table 2. Decision Matrix

\begin{tabular}{|c|c|c|c|c|}
\hline \multirow{2}{*}{ Alternative } & \multicolumn{4}{|c|}{ Criteria } \\
\cline { 2 - 5 } & $\begin{array}{c}\text { The speed of securing } \\
\text { funds }\end{array}$ & Quality of assets & $\begin{array}{c}\text { The degree of } \\
\text { execution }\end{array}$ & Safety \\
\hline Category 1 & 5 & задовољава & 4 & 50 \\
\hline Category 2 & 4 & задовољава & 5 & 40 \\
\hline Category 3 & 5 & $\begin{array}{c}\text { У потпуности } \\
\text { задовољава }\end{array}$ & 3 & 60 \\
\hline
\end{tabular}

By quantifying this matrix, using a Saaty scale12 with nine points for assigning weight, the matrix shown in Table 19 is obtained:

\footnotetext{
${ }^{11}$ The delphi method was evaluated in three circles. The selected panel consisted of ten experts who answered the questions. Their final evaluations serve to determine the experiential values of individual criteria.

${ }^{12}$ Saaty, T.: The Analytic Hierarchy Process", McGraw-Hill, New York. 1980, pp. 287.
} 
Table 3. Quantified input data

\begin{tabular}{|c|c|c|c|c|}
\hline Alternative & \multicolumn{4}{|c|}{ Criteria } \\
\hline & $\begin{array}{c}\text { The speed of } \\
\text { securing funds }\end{array}$ & $\begin{array}{c}\text { Quality of } \\
\text { assets }\end{array}$ & $\begin{array}{c}\text { The degree of } \\
\text { execution }\end{array}$ & Safety \\
\hline Category 1 & 5 & 7 & 4 & 50 \\
\hline Category 2 & 4 & 7 & 5 & 40 \\
\hline Category 3 & 5 & 9 & 3 & 60 \\
\hline
\end{tabular}

The beginning of the application of the method implies determining the relative weight of the criterion, or the significance of the criteria. To assess relative weights, Saaty's scale is used:

Table 3. Saaty Values Scale

\begin{tabular}{|c|c|c|}
\hline Importance & Definition & Explanation \\
\hline 1 & the same character & $\begin{array}{c}\text { Two elements are identical in meaning to the } \\
\text { goal }\end{array}$ \\
\hline 3 & Poor dominance & $\begin{array}{c}\text { Experience or reasoning slightly favors one } \\
\text { element in relation to the other }\end{array}$ \\
\hline 5 & Strong dominance & $\begin{array}{c}\text { Experience or judgment greatly favors one } \\
\text { element in relation to the other }\end{array}$ \\
\hline 7 & Demonstrated dominance & $\begin{array}{c}\text { The dominance of one element is confirmed in } \\
\text { practice }\end{array}$ \\
\hline 9 & Absolute dominance & Dominance of the highest degree \\
\hline $2,4,6,8$ & subtotals & Compromise needed or further division \\
\hline
\end{tabular}

Table 4. Evaluation of relative weight of criteria (calculation of author)

\begin{tabular}{|c|c|c|c|c|}
\hline Criteria & $\begin{array}{c}\text { The speed of } \\
\text { securing funds }\end{array}$ & $\begin{array}{c}\text { Quality of } \\
\text { assets }\end{array}$ & $\begin{array}{c}\text { The degree of } \\
\text { execution }\end{array}$ & Safety \\
\hline The speed of securing funds & Quality of assets & 5 & 5 & 3 \\
\hline Quality of assets & $(5)$ & 1 & 3 & $(5)$ \\
\hline The degree of execution & $(5)$ & $(3)$ & 1 & $(5)$ \\
\hline Safety & $(3)$ & 5 & 5 & 1 \\
\hline$\Sigma$ & 1,733 & 11,333 & 14 & 4,4 \\
\hline
\end{tabular}

Table 5. Calculation of own vectors of corresponding own values

\begin{tabular}{|c|c|c|c|c|c|c|}
\hline Criteria & $\begin{array}{c}\text { The speed of } \\
\text { securing funds }\end{array}$ & $\begin{array}{c}\text { Quality of } \\
\text { assets }\end{array}$ & $\begin{array}{c}\text { The degree } \\
\text { of execution }\end{array}$ & Safety & $\Sigma$ & $\mathrm{W}(\Sigma / 4)$ \\
\hline $\begin{array}{c}\text { The speed of } \\
\text { securing funds }\end{array}$ & 0,577 & 0,441 & 0,357 & 0,681 & 2,056 & 0,514 \\
\hline Quality of assets & 0,115 & 0,088 & 0,214 & 0,045 & 0,462 & 0,115 \\
\hline $\begin{array}{c}\text { The degree of } \\
\text { execution }\end{array}$ & 0,115 & 0,029 & 0,071 & 0,045 & 0,260 & 0,065 \\
\hline Safety & 0,192 & 0,441 & 0,357 & 0,227 & 1,217 & 0,304 \\
\hline
\end{tabular}

By comparing the value of the weight of the criteria obtained by using the Saaty scale and the values obtained by using the Delphi method, it can be concluded that the criterion of security rates in relation to its importance given to it in practice is overestimated. Unlike him, the 
criterion of the degree of execution should be given greater importance, which confirms the result obtained. The quality and safety criteria are well assessed by the data obtained. Based on the data obtained by estimating the relative weight of the criteria, one should consider the same method of alternatives that are available, ie three categories set. A comparison of the alternatives will be done by Saaty's rock.

Table 6. Calculation of own vectors of corresponding own values (rate of realization)

\begin{tabular}{|c|c|c|c|c|c|}
\hline Alternative & Category 1 & Category 2 & Category 3 & $\Sigma$ & $\mathrm{W}(\Sigma / 3)$ \\
\hline Category 1 & 1 & $(5)$ & $(3)$ & 0,358 & 0,119 \\
\hline Category 2 & 5 & 1 & $(3)$ & 0,993 & 0,331 \\
\hline Category 3 & 3 & 3 & 1 & 1,647 & 0,549 \\
\hline
\end{tabular}

Table 7. Calculation of own vectors of corresponding own values (quality)

\begin{tabular}{|c|c|c|c|c|c|}
\hline Alternative & Category 1 & Category 2 & Category 3 & $\Sigma$ & $\mathrm{W}(\Sigma / 3)$ \\
\hline Category 1 & 1 & 2 & $(4)$ & 0,632 & 0,210 \\
\hline Category 2 & $(2)$ & 1 & $(4)$ & 0,398 & 0,132 \\
\hline Category 3 & 4 & 4 & 1 & 1,164 & 0,654 \\
\hline
\end{tabular}

Table 8. Calculation of own vectors of corresponding own values (degree of execution)

\begin{tabular}{|c|c|c|c|c|c|}
\hline Alternative & Category 1 & Category 2 & Category 3 & $\Sigma$ & $\mathrm{W}(\Sigma / 3)$ \\
\hline Category 1 & 1 & $(3)$ & 3 & 0,780 & 0,260 \\
\hline Category 2 & 3 & 1 & 5 & 1,899 & 0,633 \\
\hline Category 3 & $(3)$ & $(5)$ & 1 & 0,317 & 0,654 \\
\hline
\end{tabular}

Table 9. Calculation of own vectors of corresponding own values (security)

\begin{tabular}{|c|c|c|c|c|c|}
\hline Alternative & Category 1 & Category 2 & Category 3 & $\Sigma$ & $\mathrm{W}(\Sigma / 3)$ \\
\hline Category 1 & 1 & $(5)$ & $(3)$ & 0,317 & 0,105 \\
\hline Category 2 & 5 & 1 & 3 & 1,899 & 0,633 \\
\hline Category 3 & 3 & $(3)$ & 1 & 0,780 & 0,260 \\
\hline
\end{tabular}

After the formation of the comparison table, the weights in pairs for each alternative were separately calculated by the own vector. In this way, we have gained the weight of any alternatives essential for determining the solution to the problem. 


\section{MODEL APPLICATION ON THE SUPPLY SELECTION}

After assessing the relative weight of the alternative in relation to each criterion, it is approached to determine the category of asset provision, which has the highest value in relation to the criteria observed. The choice of a category is based on the obtained own vector alternatives and previously obtained own vectors of the criteria. The overall priorities of the alternatives are obtained by multiplying each weight for each alternative within the observed criterion in order, and in the end, the results obtained are summed up.

Table 10. Choice of the most favorable supplier

\begin{tabular}{|c|c|c|c|c|c|}
\hline & $\begin{array}{c}\text { The speed of } \\
\text { securing funds }\end{array}$ & $\begin{array}{c}\text { Quality of } \\
\text { assets }\end{array}$ & $\begin{array}{c}\text { The degree of } \\
\text { execution }\end{array}$ & Safety & $\begin{array}{c}\text { The overall } \\
\text { priorities of the } \\
\text { alternative }\end{array}$ \\
\hline Category 1 & 0,514 & 0,115 & 0,065 & 0,304 & 0,139 \\
\hline Category 2 & 0,119 & 0,210 & 0,260 & 0,105 & 0,418 \\
\hline Category 3 & 0,331 & 0,132 & 0,633 & 0,633 & 0,442 \\
\hline
\end{tabular}

From Table 10 it can be concluded that after the implementation of the AHP method, in the research, the order of alternatives would be the following: "Category 1" (14\%), "Category 2" (42\%), "Category 3 " (44\%), it can be seen that in relation to the given criteria "Category 3", that is, procurements realized by the negotiation procedure with the announcement of a call for bids in which the most economically advantageous tender with the elements of the delivery deadline is taken as a criterion, the obligations regarding the maintenance period and the capacities of the bidders have the highest value.

\section{CONCLUSION}

The agroindustrial complex is characterized by the integrity of the production process, which also determines the integrity of the supply. Using quantitative models can provide a good basis for decision-makers, although in these models the decision maker's subjectivity is present, in assessing the relative weight of criteria and alternatives, it can be diminished by combining several different methods of multi-criteria optimization and comparison of the solution. The application of this model in the research found that the suppliers with the highest value of the most economically advantageous offer with elements of delivery deadline, obligations regarding the maintenance period and the capacities of the bidders showed the best estimations when the procurement was carried out for the given assessment parameters. These procurements also had the highest value in terms of the speed of implementation, which influenced the adequate provision of funds from the producers of the agro-industrial complex. The survey found that procurements for which multiple criteria were used to evaluate the bids were implemented more quickly.

This research has proven that suppliers who have respected the deadline for securing funds and who had better capacities in line with the required level were reliable and safe, which also affected the integrity of the suppliers of the pre-industrial complex. Also, in the research, the decision support system showed that the reliability of the supplier is correlated with its business capacity indicators.

The paper is part of the research at the project III-46006 "Sustainable agriculture and rural development in terms of the Republic of Serbia strategic goals realization within the Danube region", financed by the Ministry of Education, Science and Technological Development of the Republic of Serbia." 


\section{REFERENCES}

[1]Duin, D., Krstić, D., Nešić, B., \& Kaluđerović, N. (2017). Revizija svrsishodnosti javnih nabavki budžetskih korisnika. Oditor - časopis za Menadžment, finansije i pravo, 3(3), 61-72.

[2]Jovović, D., \& Jovović, D. (2018). Konkurentnost prehrambene industrije Republike Srbije. Ekonomika poljoprivrede, 65(1), 49-64.

[3]Pamučar, D., Đorović, B., Božanić, D., Ćirović, G.: Modification of the Dynamic Scale of Marks in Analytic Hierarchy Process (AHP) and Analytic Network Approach (ANP) through Application of Fuzzy Approach, Scientific Research and Essays, Vol. 7(1), 2012, pp. 24-37.

[4]Popović S, Janković I, Stojanović Ž., The importance of bank credits for agricultural financing in Serbia, 2018, vol. 65, br. 1, str. 65-80

[5]Saaty, T.: The Analytic Hierarchy Process", McGraw-Hill, New York. 1980.

[6]Čavlin, M., Žugić, R., \& Prebiračević, V. (2017). Karakter planiranja kao funkcije menadžmenta. Oditor - časopis za Menadžment, finansije i pravo, 3(1), 102-113. www.odlucivanje.fon.rs

[7]Mihajlović. M., Dašić, M., Pamučar, D.: Primena AHP metode prilikom nabavke opreme za objekte ishrane u sistemu odbrane, 34. Simpozijum o operacionim istraživanjima, SYM-OP-IS 2012, str. 409-412

[8]Pavličić, D.: Teorija odlučivanja, Ekonomski fakultet Beograd, Beograd, 2010.

[9]Petrović, D., i dr.: Menadžment i organizacija, Fakultet organizacionih nauka, Beograd, 2012.

[10]Rađenović, Ž.: Uticaj politike konkurencije na državnu pomoć i javni sektor u okviru jednstvenog tržišta Evropske unije, Facta universitatis - series: Economics and Organization, Vol. 12, br. 1, 2015, str. 83-95

[11]Čupić, M., Suknović, M.: Odlučivanje, Fakultet organizacionih nauka, Beograd, 2010. [12]Vilke, R., Gedminaite-Raudone, Z., \& Cvijanović, D. (2019). Future drivers of rural prosperity in knowledge age: Lithuanian case. Ekonomika poljoprivrede, 66(1), 143-157.

[13]Krstić B., Vasiljević Z., Nedeljković M. (2017) Ugovor o osiguranju kao osnov sigurnosti poljoprivrednih proizvođača u Republici Srpskoj, Ekonomika poljoprivrede, 64(4), 1555-1570 